\title{
Singlet Oxygen-Mediated Synthesis of Bis-spiroketals Found in Azaspiracids
}

\author{
Myron Triantafyllakis, Maria Tofi, Tamsyn Montagnon, Antonia Kouridaki and Georgios \\ Vassilikogiannakis*
}

Department of Chemistry, University of Crete, Vasilika Vouton, 71003 Iraklion, Crete, Greece

Supporting Information Placeholder

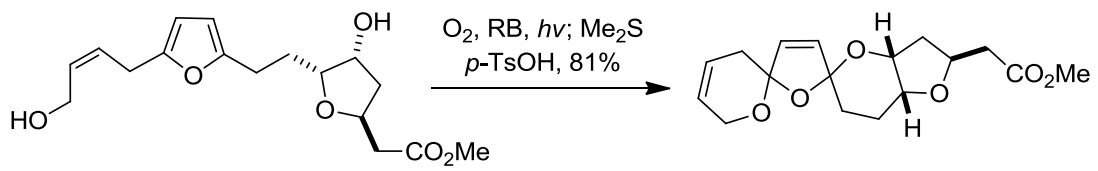

ABSTRACT: Conversion of a simple furan into the ABCD-ring skeleton of the azaspiracids via a singlet oxygen-initiated one-pot process has been accomplished.

Many natural products such as the ionophore antibiotics ${ }^{1}$ salinomycin and narasin, or the marine toxins pinnatoxins/pteriatoxins, ${ }^{2}$ spirolides ${ }^{3}$ and azaspiracids $^{4}$ contain bisspiroketal motifs. ${ }^{5}$ These molecules have become increasingly popular as synthetic targets due to the combination of their promise as new anticancer therapies (a consequence of their potent cytotoxicity) and the fact that they possess complex, yet fragile, 3D-architectures that offer a number of challenges which synthetic chemists find hard to resist. The traditional approach to such structures has the stepwise construction of a linear precursor precede an acid-catalysed ketalisationcyclisation event (or, more usually, several events) and many syntheses have been accomplished in this manner. ${ }^{5}$ Others have sought to design new methods to make bis-spiroketals that avoid some of the efficiency pitfalls (e.g. the heavy use of concessionary steps, ${ }^{6}$ protections/deprotections, ${ }^{7}$ and nonstrategic redox manipulations ${ }^{8}$ ) that abound in the more traditional chemistry of polyoxygenated polycycles. Amongst these alternative ideas, we were inspired by the use of furan oxidations as a starting point for the synthesis of bis-spiroketals. ${ }^{9-12}$ The application of this approach, however, has frequently been limited to simple substrates in response to the harsh/nonselective oxidants employed $\left(\mathrm{Br}_{2},{ }^{9} \mathrm{NBS},{ }^{10}\right.$ electrochemical oxidation $^{11}$ ). A noteworthy exception to the "simple substrate"-limitation is to be found within the investigations that culminated in elegant total syntheses of salinomycin by Kocieński's group published in the 1990s. ${ }^{10 \mathrm{~b}, 12}$

We believed that we could use singlet oxygen as a clean and selective oxidant ${ }^{13}$ to synthesize this key motif, and, in addition we felt that we could do it in a way that formed both of the rings flanking the central five-membered ring of the bisspiroketal unit in one operation. Indeed, this turned out to be the case so that, starting from simple and readily accessible furan substrates, we were able to obtain either [5,5,5]- or $[6,5,6]$-bis-spiroketals directly in high yield (Scheme 1). ${ }^{14,15}$
This method could be successfully adapted to include a further rearrangement during the course of the reaction sequence such that it now gave access to a $[6,6,5]$-bis-spiroketal motif ${ }^{16}$ (Scheme 1) of the type found in salinomycin as NBSprecedent had suggested was possible. ${ }^{10 b, 12}$ With these simple examples delineated (just one substrate for [5,5,5]-bisspiroketal and two basic substrates for [6,5,6]-bis-spiroketals) we now hoped to extend the work and design a more advanced cascade. This would include additional and potentially competing hydroxyl-functionalities that would efficiently deliver new ring systems, such as the ABCD-rings of the azaspiracids.

Scheme 1. Synthesis of bis-spiroketals using ${ }^{1} \mathrm{O}_{2}$
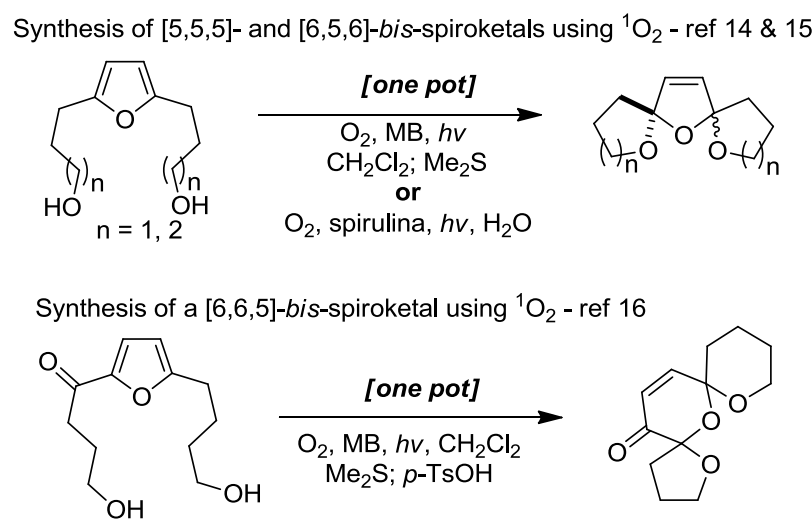

Azaspiracid-1 (1, Figure 1) was first isolated from the blue mussel Mytilus edulis in 1998 by Yasumoto and co-workers. ${ }^{17}$ Two closely related analogues of $\mathbf{1}$, azaspiracids-2 and 3 (2 and $\mathbf{3}$, Figure 1), were isolated by the same team one year later. ${ }^{18}$ The azaspiracids have shown a range of interesting biological activities, ${ }^{19}$ including, the recently discovered inhibition of the hERG ion channel. ${ }^{20}$ A synthesis of the structure originally proposed for azaspiracid-1 was reported by 


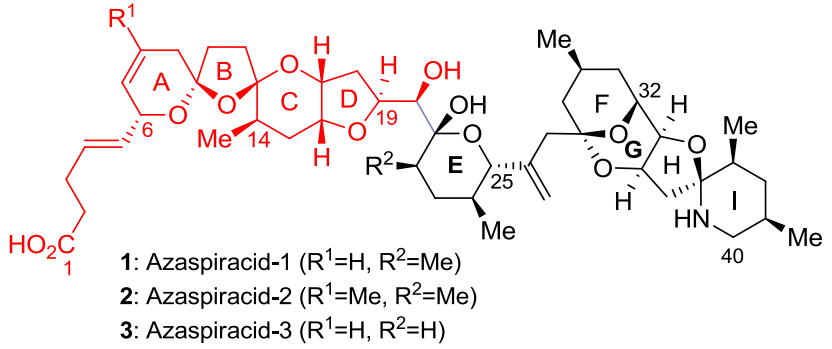

Figure 1. The Azaspiracids

Nicolaou and his co-workers in 2003. However, it was found that the spectroscopic data for this synthetic compound did not match that of the natural isolate. ${ }^{21}$ The same team then revised the structure to that shown in Figure 1 based on degradation studies, the synthesis of different diastereoisomers, and, as final confirmation, the first total synthesis of azaspiracid-1 (1). ${ }^{22}$ They also completed total syntheses of the revised structures of azaspiracid-2 and -3 ( 2 and 3 ) in $2006,{ }^{23}$ as well as, shorter second generation total syntheses of all three azaspiracids (1-3). ${ }^{4 a}$ In the following year, a concise total synthesis of ent-azaspiracid-1 (ent-1) was accomplished by Evans and his co-workers. ${ }^{4 \mathrm{~b}, 24}$ Different approaches to the ABCD-domain of these complex molecules have been reported. ${ }^{25}$

The strategy we were now seeking to implement for the construction of the ABCD-ring skeleton of the azaspiracids involved the photooxygenation of furan precursors of type 4 (Figure 2) followed by a cyclisation cascade reaction sequence, as its key step. The presence in the substrate of unprotected hydroxyl functionalities and an electron rich allylic alcohol are notable as these would interfere with most other oxidation-cyclisation strategies. Furthermore, the presence of both a $\gamma$ - and a $\delta$-hydroxyl, either of which could engage with the initially formed intermediate endoperoxide to afford the [6,5,5]-bis-spiroketal, or the [6,5,6]-bis-spiroketal, respectively, had introduced a possible competition within the cascade reaction sequence the outcome of which was uncertain for it had not been investigated as part of the original and much more basic bis-spiroketal formation study. ${ }^{14}$<smiles>[R]C[C@H](O)[C@@H](O)[13CH]=Cc1ccc(C/C=C\CO)o1</smiles>

$$
\begin{aligned}
& \text { 4a: } \mathrm{R}=\mathrm{Me} \\
& \text { 4b: } \mathrm{R}=z_{2}<\mathrm{OH} \\
& \text { 4c: } \mathrm{R}=3 \text { 年 } \mathrm{CO}_{2} \mathrm{Me}
\end{aligned}
$$

\section{Figure 2. Photooxidation Precursors}

The first task for this investigation was therefore to clarify which of these two possible products would dominate in the key step of the proposed approach. To answer this question, a simple model system that was easily synthesised (in just 4 steps from furan) furan triol $\mathbf{4 a}$ (Scheme 2) was used. It is important to note that the dihydroxylation reaction of deprotected 9 was completely regioselective leaving the double bond of the allylic alcohol untouched. Furan $4 \mathbf{a}$ was then subjected to the singlet oxygen $\left({ }^{1} \mathrm{O}_{2}\right)$ oxidation conditions routinely used in our laboratories to affect such transformations. Oxygen was bubbled through the reaction solution that had $10^{-4} \mathrm{M}$ methylene blue added as sensitizer and the solution was irradiated with visible spectrum light until complete consumption of the starting material was observed by tlc (1.5 min). After the addition of dimethyl sulfide, as an in situ reductant for the intermediate spiro-hydroperoxide (not shown $),{ }^{14}$ and addition of catalytic $p$-TsOH $\cdot \mathrm{H}_{2} \mathrm{O}$, the $[6,5,5]-$ bis-spiroketal $\mathbf{1 0}$ was isolated as the product of the reaction, (consisting of four partially separable diastereoisomers). ${ }^{26}$ The assignment of the final bis-spiroketal as being the [6,5,5]-bisspiroketal instead of the desired $[6,5,6]$-variant derived from comparisons between the ${ }^{13} \mathrm{C}-\mathrm{NMR}$ chemical shifts of the ketal carbons in this and known [5,5,5]- and [6,5,6]-bisspiroketals. ${ }^{14,27}$ Further proof came from the oxidation of $\mathbf{1 0}$ to the corresponding ketone (not shown), which resulted in a downfield shift of the $-\mathrm{CH}_{2}$ - protons " $\alpha$ " to the newly formed carbonyl, as well as, simplification of their coupling patterns.

Scheme 2. A Model Study: Formation of a [6,5,5]-Bisspiroketal
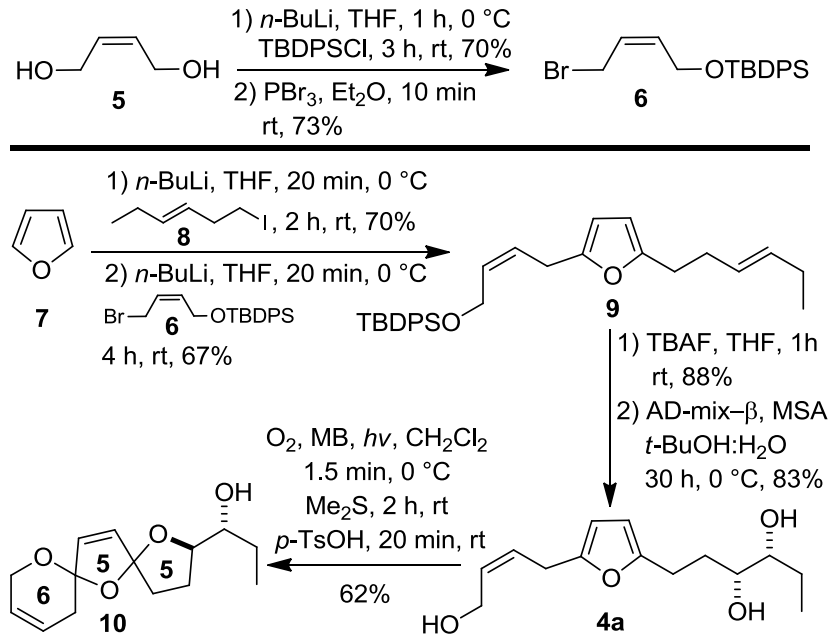

The unwanted outcome for this singlet oxygen-initiated spiroketalization of the model furan $\mathbf{4 a}$, indicated to us that the $\gamma-\mathrm{OH}$ group of the photooxidation precursor needed to be protected such that only the $\delta$-positioned hydroxyl was left free to ketalise and form the desired [6,5,6]-bis-spiroketal. Wishing to avoid the use of concessionary steps ${ }^{6}$ and classical protecting groups, we opted to pursue another idea, namely, that the presence of an epoxide (4b, Figure 2), or an $\alpha, \beta$-unsatutated ester $(\mathbf{4 c})$, in the starting substrate could serve a dual purpose, "protection" of the $\gamma$-positioned oxygen atom, as well as, offering a means to construct of the requisite 5-membered Dring.

To access the furan-tetrol $\mathbf{4 b}, 2,5$-disubstituted furan $\mathbf{1 3}$ (Scheme 3) was prepared by two sequential ortho-alkylations of furan (7). Deprotection of the TBS-ether was followed by Dess-Martin periodinane (DMP) oxidation of the resulting primary alcohol affording the corresponding aldehyde and then, by in situ Wittig reaction with a stabilized ylide, the $\alpha, \beta$-unsaturated ester 14 (55\% overall yield over 3 steps) was accessed. Reduction of the ester group using Dibal-H was followed by Sharpless epoxidation of the resulting allylic alcohol. Deprotection of the TBDPS-ether afforded the epoxide 15. Regioselective dihydroxylation of $\mathbf{1 5}$ resulted in the formation of a complicated mixture of tetrol $\mathbf{4 b}$ and its diastereoisomer accompanied by THF-ethers $\mathbf{1 6 \mathbf { a }}$ and $\mathbf{1 6} \mathbf{b}$, products of the desired 5-exo epoxide opening. This complicated mixture was treated with PPTS, which encouraged exclusive formation of the diastereoisomeric THF-ethers $\mathbf{1 6 a}$ and $\mathbf{1 6} \mathbf{b}$ in a ratio which varied from $3: 2$ to $2: 1$. The fact that the major diastereoisomer 16a had the desired 
Scheme 3. Synthesis of the ABCD-Ring Skeleton of Azaspiracids in the Form of 17a

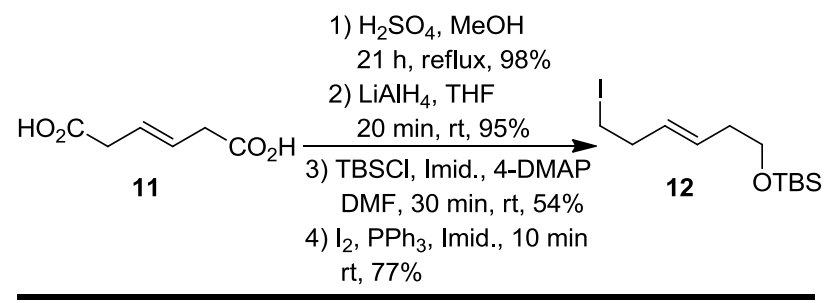

1) $n$-BuLi, THF, $20 \mathrm{~min}, 0^{\circ} \mathrm{C}$

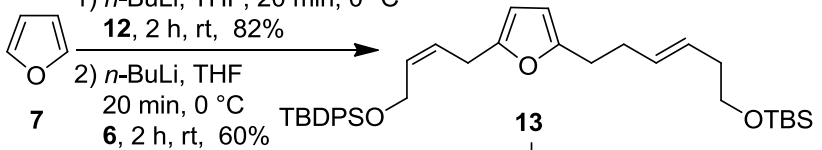

1) $p$ - $\mathrm{TsOH}, \mathrm{THF}: \mathrm{H}_{2} \mathrm{O}, 24 \mathrm{~h}, \mathrm{rt}, 92 \%$

2) DMP, $\mathrm{CH}_{2} \mathrm{Cl}_{2}, 40 \mathrm{~min}, 0^{\circ} \mathrm{C}$

$\mathrm{Ph}_{3} \mathrm{P}=\mathrm{CO}_{2} \mathrm{Me}, 24 \mathrm{~h}, \mathrm{rt}, 60 \%$

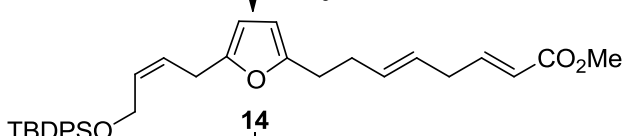

1) Dibal-H, THF, $1 \mathrm{~h},-78{ }^{\circ} \mathrm{C}$ to $\mathrm{rt}, 97 \%$

2) $D$-DET, $\mathrm{Ti}(\mathrm{OiPr})_{4}, \mathrm{CH}_{2} \mathrm{Cl}_{2}, 5 \mathrm{~min}, 0^{\circ} \mathrm{C}$ $t$ - $\mathrm{BuOOH}, 20 \mathrm{~min},-20^{\circ} \mathrm{C}$, substrate

$48 \mathrm{~h},-20^{\circ} \mathrm{C}, 55 \%$

3) TBAF, THF, $2.5 \mathrm{~h}, \mathrm{rt}, 90 \%$

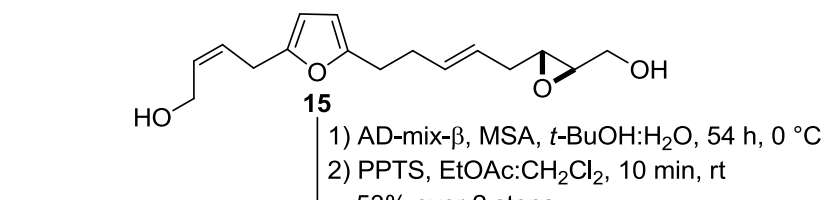

2) PPTS, EtOAc: $\mathrm{CH}_{2} \mathrm{Cl}_{2}, 10 \mathrm{~min}$, rt $53 \%$ over 2 steps

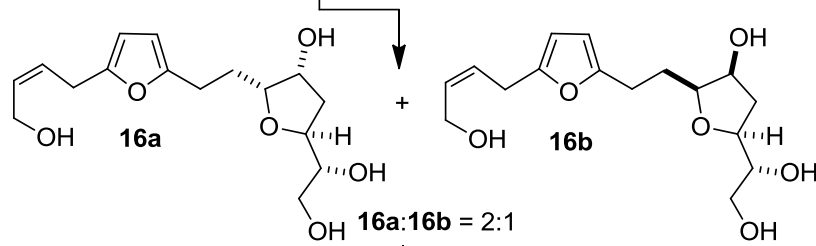

$\mathrm{O}_{2}, \mathrm{RB}, h v, \mathrm{MeOH}, 1 \mathrm{~min}, 0^{\circ} \mathrm{C}$

$\mathrm{Me}_{2} \mathrm{~S}, \mathrm{CH}_{2} \mathrm{Cl}_{2}, 3 \mathrm{~h}, \mathrm{rt}$

$p$-TsOH, $10 \mathrm{~min}, \mathrm{rt}, 61 \%$

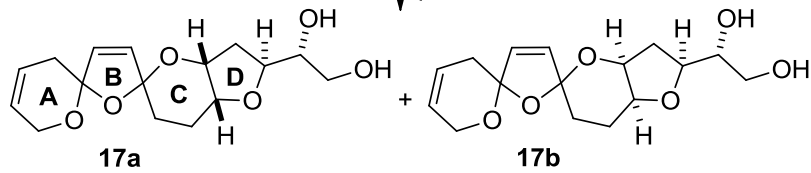

stereochemistry was unambiguously confirmed by extensive NOE-studies of both diastereoisomers. ${ }^{27}$ This diastereoisomeric ratio directly reflects the diastereoselectivity of the dihydroxylation reaction.

The stage was now set, with only the $\delta$-positioned hydroxyl left free to ketalise, for the key ${ }^{1} \mathrm{O}_{2}$-mediated reaction. When the inseparable mixture of $\mathbf{1 6 a}$ and $\mathbf{1 6} \mathbf{b}$ was subjected to the photooxidation conditions in $\mathrm{MeOH}$ (tetrols $\mathbf{1 6 a}$ and $\mathbf{1 6 b}$ were not very soluble in $\mathrm{CH}_{2} \mathrm{Cl}_{2}$ ), using Rose Bengal as photosensitizer, an inseparable mixture of tetracycles $\mathbf{1 7} \mathbf{a}$ and $\mathbf{1 7 b}$ was isolated in $61 \%$ yield. It is important to note that when the complicated mixture of 4 compounds (from before treatment with PPTS) was subjected to the ${ }^{1} \mathrm{O}_{2}$ oxidation conditions, exactly the same mixture of desired $[6,5,6]$-bis-spiroketals 17a and $\mathbf{1 7 b}$ was isolated and none of the undesired [6,5,5]-bis- spiroketal of type $\mathbf{1 0}$ (as had been seen in the model study) was observed. At this point, it is important to mention that both 17a and 17b appear in the NMR as a 1:1 mixture of two diastereoisomers ${ }^{27}$ which means that the spiroketalization reaction led to only two out of the four possible diastereoisomers. This could arise as a result of the anomeric effect, or from energy differences between the cis- and trans- bisspiroketals. $^{25 \mathrm{e}, \mathrm{g}, \mathrm{j}-1}$

The drawback of this very short synthetic sequence is the low diastereselectivity of the dihydroxylation of $\mathbf{1 5}$ which resulted in the formation of two inseparable diastereomers 16a,b. Despite the fact that the major diastereoisomer has the desired stereochemistry at the newly formed THF-ring (Dring), it would have been a more attractive approach if the crucial photooxidation/bis-spiroketalization step could be run on only the correct isomer. This led us to explore the use of compound $\mathbf{4 c}$. TBDPS-protected $\mathbf{4 c}$ was synthesized by regioselective dihydroxylation of triene 14. MeONa-mediated intramolecular oxa-Michael reaction followed by TBAFmediated deprotection of the allylic alcohol resulted in the formation of two separable THF-ethers 18 in 8:1 ratio. Extensive NOE studies proved that the major diastereomer was the correct one. ${ }^{27}$ With the desired diastereomer now separated from its minor isomer and in hand, the key singlet oxygeninitiated bis-spiroketalization cascade reaction sequence was again tested. This reaction now afforded a mixture of only two, and, in this case, almost completely separable diastereoisomers of 19 in 1:1 ratio. Extensive 2D-NMR experiments and NOE studies were run on both distereoisomers. No NOEs were seen between the A- and C-ring protons, thus any stereochemical assignment at the spiroketal centres would be tentative, these observations are in keeping with precedent in other similar systems. ${ }^{25,26}$ Attempts at obtaining crystals for X-ray diffraction were unsuccessful.

Scheme 4. Synthesis of the ABCD-Ring Skeleton of Azaspiracids in the Form of 19

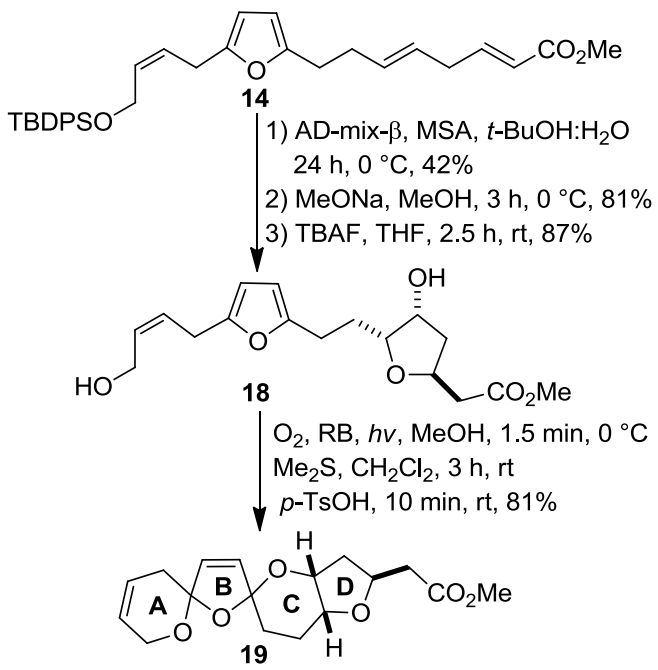

The synthetic strategy developed herein to access this type of tetracycle is highly advantageous since it rapidly constructs the carbon backbone of the targeted molecular fragment (the ABCD-ring system of azaspiracid), in the form of furan 14, leaving the inclusion of the central oxygens to the two (or three) chemoselective oxidations (epoxidation, dihydroxylation and ${ }^{1} \mathrm{O}_{2}$ furan photooxidation) that terminate 
the sequence. The strategy uses a minimal number of concessionary steps, ${ }^{6}$ non-strategic redox manipulations ${ }^{8}$ and protecting groups, ${ }^{7}$ thus taking a step closer to the sustainable ideal. Lastly, the final one-pot reaction sequence initiated by ${ }^{1} \mathrm{O}_{2}$ is particularly notable for its rapid increase in three-dimensional molecular complexity from a very simple starting point.

\section{ASSOCIATED CONTENT}

\section{Supporting Information}

Experimental procedures, full spectroscopic data and copies of ${ }^{1} \mathrm{H}$ and ${ }^{13} \mathrm{C}$-NMR spectra for all new compounds. This material is available free of charge via the Internet at http://pubs.acs.org.

\section{AUTHOR INFORMATION}

\section{Corresponding Author}

*E-mail: vasil@chemistry.uoc.gr

\section{Author Contributions}

The manuscript was written through contributions of all authors. All authors have given approval to the final version of the manuscript.

\section{Notes}

The authors declare no competing financial interest.

\section{ACKNOWLEDGMENT}

The research leading to these results has received funding from the European Research Council under the European Union's Seventh Framework Programme (FP7/2007-2013)/ERC grant agreement no. 277588 .

\section{REFERENCES}

(1) For a review in polyether ionophores, see: Dutton, C. J.; Banks, B. J.; Cooper, C. B. Nat. Prod. Rep. 1995, 12, 165.

(2) For a review of the isolation investigations, see: Kita, M.; Uemura, D. Chem. Lett. 2005, 34, 454.

(3) For the original isolation paper, see: Hu, T.; Curtis, J. M.; Oshima, Y.; Quilliam, M. A.; Walter, J. A.; Watson-Wright, W. M.; Wright, J. L. C. J. Chem. Soc., Chem. Commun. 1995, 2159.

(4) For leading references, see: (a) Nicolaou, K. C.; Frederick, M. O.; Loizidou, E. Z.; Petrovic, G.; Cole, K. P.; Koftis, T. V.; Yamada, Y. M. A. Chem. Asian J. 2006, 1, 245. (b) Evans, D. A.; Kværnø, L.; Dunn, T. B.; Beauchemin, A.; Raymer, B.; Mulder, J. A.; Olhava, E. J.; Juhl, M.; Kagechika, K.; Favor, D. A. J. Am. Chem. Soc. 2008, 130,16295

(5) For selected reviews, see: (a) Brimble, M. A.; Farès, F. A. Tetrahedron, 1999, 55, 7661. (b) Carter, R. G.; Kuiper, D. L. Asymmetric Synthesis of Spiroketals, Bisspiroketals, and Spiroaminals. In Stereoselective Synthesis, Molander, G. A. Ed.; Thieme: Stuttgart, New York 2010, Vol 2, pp 863-914.

(6) (a) Newhouse, T.; Baran, P. S.; Hoffmann, R. W.; Chem. Soc. Rev. 2009, 38, 3010. (b) Gaich, T.; Baran, P. S. J. Org. Chem. 2010 75,4657 .

(7) (a) Hoffmann, R. W. Synthesis, 2006, 3531. (b) Young, I. S.; Baran, P. S. Nat. Chem., 2009, 1, 193.

(8) Burns, N. Z.; Baran, P. S.; Hoffmann, R. W. Angew. Chem. Int. Ed., 2009, 48, 2854.

(9) (a) Whitby, R.; Kocieński, P. J. Chem. Soc., Chem. Commun., 1987, 906. (b) Kocieński, P.; Fall, Y.; Whitby, R. J. Chem. Soc., Perkin Trans. 1, 1989, 841.

(10) (a) Perron, F.; Albizati, K. F. J. Org. Chem., 1989, 54, 2044; (b) Brown, R. C. D.; Kocieński, P. J. Synlett, 1994, 417; (c) McDermott, P. J.; Stockman, R. A. Org. Lett. 2005, 7, 27.

(11) Ponomarev, A. A.; Markushina, I. A. Zh. Obshch. Khim., 1963, 33, 3955

(12) Kocieński, P. J.; Brown, R. C. D.; Pommier, A.; Procter M.; Schmidt, B. J. Chem. Soc., Perkin Trans. 1, 1998, 9.
(13) For reviews, see: (a) Montagnon, T.; Tofi, M.; Vassilikogiannakis G. Acc. Chem. Res. 2008, 41, 1001. (b) Margaros, I.; Montagnon, T.; Tofi, M.; Pavlakos, E.; Vassilikogiannakis, G. Tetrahedron, 2006, 62, 5308. (c) Montagnon, T.; Noutsias, D.; Alexopoulou, I.; Tofi. M.; Vassilikogiannakis, G. Org. Biomol. Chem. 2011, 9, 2031.

(14) Georgiou, T.; Tofi, M.; Montagnon, T.; Vassilikogiannakis, G. Org. Lett. 2006, 8, 1945.

(15) Noutsias, D.; Alexopoulou, I.; Montagnon T.; Vassilikogiannakis, G. Green Chem. 2012, 14, 601.

(16) Tofi, M.; Montagnon, T.; Georgiou T.; Vassilikogiannakis, G. Org. Biomol. Chem., 2007, 5, 772.

(17) Satake, M.; Ofuji, K.; Naoki, H.; James, K. J.; Furey, A.; McMahon, T.; Silke, J.; Yasumoto, T. J. Am. Chem. Soc. 1998, 120, 9967.

(18) Ofuji, K.; Satake, M.; McMahon, T.; Silke, J.; James, K. J.; Naoki, H.; Oshima, Y.; Yasumoto, T. Nat. Toxins 1999, 7, 99.

(19) (a) McMahon, T.; Silke, J. Harmful Algae News 1996, 14, 2. (b) Twiner, M. J.; Rehmann, N.; Hess, P.; Doucette, G. J. Marine Drugs 2008, 6, 39. (c) Furey, A.; O’Doherty, S.; O'Callaghan, K.; Lehane, M.; James, K. J. Toxicon 2010, 56, 173.

(20) Twiner, M. J.; Doucette, G. J.; Rasky, A.; Huang, X.-P.; Roth, B. L.; Sanguinetti, M. C. Chem. Res. Toxicol. 2012, 25, 1975.

(21) (a) Nicolaou, K. C.; Li, Y.; Uesaka, N.; Koftis, T. V.; Vyskocil, S.; Ling, T.; Govindasamy, M.; Qian, W.; Bernal, F.; Chen, D. Y. K. Angew. Chem., Int. Ed. 2003, 42, 3643. (b) Nicolaou, K. C.; Chen, D. Y. K.; Li, Y.; Qian, W.; Ling, T.; Vyskocil, S.; Koftis, T. V.; Govindasamy, M.; Uesaka, N. Angew. Chem., Int. Ed. 2003, 42, 3649. (c) Nicolaou, K. C.; Pihko, P. M.; Bernal, F.; Frederick, M. O.; Qian, W.; Uesaka, N.; Diedrichs, N.; Hinrichs, J.; Koftis, T. V.; Loizidou, E. Z.; Petrovic, G.; Rodriquez, M.; Sarlah, D.; Zou, N. J. Am. Chem. Soc. 2006, 128, 2244. (d) Nicolaou, K. C.; Chen, D. Y. K.; Li, Y.; Uesaka, N.; Petrovic, G.; Koftis, T. V.; Bernal, F.; Frederick, M. O.; Govindasamy, M.; Ling, T.; Pihko, P. M.; Tang, W.; Vyskocil, S. J. Am. Chem. Soc. 2006, 128, 2258.

(22) (a) Nicolaou, K. C.; Vyskocil, S.; Koftis, T. V.; Yamada, Y. M. A.; Ling, T.; Chen, D. Y. K.; Tang, W.; Petrovic, G.; Frederick, M. O.; Li, Y.; Satake, M. Angew. Chem., Int. Ed. 2004, 43, 4312. (b) Nicolaou, K. C.; Koftis, T. V.; Vyskocil, S.; Petrovic, G.; Ling, T.; Yamada, Y. M. A.; Tang, W.; Frederick, M. O. Angew. Chem., Int. Ed. 2004, 43, 4318. (c) Nicolaou, K. C.; Koftis, T. V.; Vyskocil, S.; Petrovic, G.; Tang, W.; Frederick, M. O.; Chen, D. Y. K.; Li, Y.; Ling, T.; Yamada, Y. M. A. J. Am. Chem. Soc. 2006, 128, 2859.

(23) Nicolaou, K. C.; Frederick, M. O.; Petrovic, G.; Cole, K. P.; Loizidou, E. Z. Angew. Chem., Int. Ed. 2006, 45, 2609.

(24) (a) Evans, D. A.; Kværnø, L.; Mulder, J. A.; Raymer, B.; Dunn, T. B.; Beauchemin, A.; Olhava, E. J.; Juhl, M.; Kagechika, K. Angew. Chem., Int. Ed. 2007, 46, 4693. (b) Evans, D. A.; Dunn, T. B.; Kværnø, L.; Beauchemin, A.; Raymer, B.; Olhava, E. J.; Mulder, J. A.; Juhl, M.; Kagechika, K.; Favor, D. A. Angew. Chem., Int. Ed. 2007, 46, 4698 .

(25) For selected examples, see: (a) Zhang, Z.; Ding, Y.; Xu, J.; Chen, Y.; Forsyth, C. J. Org. Lett. 2013, 15, 2338. (b) Li, X.; Li, J.; Mootoo, D. R. Org. Lett. 2007, 9, 4303. (c) Yadav, J. S.; Joyasawal, S.; Dutta, S. K.; Kunwar, A. C. Tetrahedron Lett. 2007, 48, 5335. (d) Li, Y.; Zhou, F.; Forsyth, C. J. Angew. Chem. Int. Ed. 2007, 46, 279. (e) Zhou, X.-T.; Carter, R. G. Angew. Chem. Int. Ed. 2006, 45, 1787. (f) Geisler, L. K.; Nguyen, S.; Forsyth, C. J. Org Lett. 2004, 6, 4159. (g) Zhou, X.-T.; Carter, R. G. Chem. Commun. 2004, 10, 2138. (h) Ishikawa, Y.; Nishiyama, S. Heterocycles 2004, 63, 885. (i) Ishikawa, Y.; Nishiyama, S. Tetrahedron Lett. 2004, 45, 351. (j) Carter, R. G.; Bourland, T. C.; Zhou, X.-T.; Gronemeyer, M. A. Tetrahedron 2003, 59, 8963. (k) Carter, R. G.; Graves, D. E.; Gronemeyer, M. A.; Tschumper, G. S. Org. Lett. 2002, 4, 2181. (1) Carter, R. G.; Graves, D. E. Tetrahedron Lett. 2001, 42, 6035. (m) Dounay, A. B.; Forsyth, C. J. Org. Lett. 2001, 3, 975.

(26) For a recently published bis-spiroketal methodology giving all expected inseparable diastereoisomers, see: Labarre-Lainé, J.; Beniazza, R.; Desvergnes, V.; Landais, Y. Org. Lett. 2013, 15, 4706.

(27) For more details see the Supporting Information. 
